\title{
Prevalence and factors associated with stunting among school children in Egypt
}

Ahmed Hamed, ${ }^{1}$ Ahmed Hegab ${ }^{2}$ and Eman Roshdy ${ }^{1}$

${ }^{1}$ Department of Public Health and Community Medicine, Faculty of Medicine, Sohag University, Sohag, Egypt. ${ }^{2}$ Department of Paediatrics, Faculty of Medicine, Sohag University, Sohag, Egypt. (Correspondence to: Eman Mohamed: roshdyeman@gmail.com).

\begin{abstract}
Background: Stunting adversely affects children's health and development. Few studies on the prevalence of stunting and factors associated with stunting have been done in Upper Egypt.

Aims: This study aimed to determine the prevalence of and factors associated with stunting in schoolchildren in Sohag, Egypt.

Methods: This was a cross-sectional study conducted in 2017 in Sohag governorate. Two public schools were randomly selected (one urban, one rural) and all children in these schools aged 4-12 years whose parents consented were included in the study. Parents were interviewed to collect data on child and family characteristics. The children were examined for vitamin deficiency, anaemia and parasitic infection, and body mass index was calculated. Multivariate logistic regression analysis was done to determine factors significantly associated with stunting; odds ratios (ORs) and $95 \%$ confidence intervals (CIs) are given.
\end{abstract}

Results: A total of 1786 children were included (response rate 69\%), of whom $329(18.4 \%)$ were stunted (-2 z-score and below). Factors significantly associated with stunting were: parasite infestation (OR = 1.8, 95\% CI: 1.3 -2.5), anaemia (OR $=1.7,95 \%$ CI: 1.3-2.7), low body mass index ( $\mathrm{OR}=1.2,95 \% \mathrm{CI}: 1.1-1.3)$, frequent gastroenteritis $(\mathrm{OR}=1.1,95 \% \mathrm{CI}: 1.06-1.2)$, first-cousin consanguinity of parents (OR $=1.3,95 \% \mathrm{CI}: 1.2-1.6)$ and familial short stature (OR $=1.5,95 \%$ CI: 1.2-2.1).

Conclusion: Screening and treatment of parasitic infestation, provision of iron/multivitamin supplementation and education on healthy nutrition should be part of school health programmes to prevent stunting in schoolchildren in Sohag.

Keywords: Stunting, schoolchildren, Egypt

Citation: Hamed A; Hegab A; Mohamed E. Prevalence and factors associated with stunting among schoolchildren in Egypt. East Mediterr Health J. 2020;26(7):787-793. https://doi.org/10.26719/emhj.20.047

Received: 12/09/17; accepted: 15/10/18

Copyright (C) World Health Organization (WHO) 2020. Open Access. Some rights reserved. This work is available under the CC BY-NC-SA 3.0 IGO

license (https://creativecommons.org/licenses/by-nc-sa/3.o/igo)

\section{Introduction}

Stunted growth is defined as a height-for-age z-score of 2 standard deviations (SDs) or more below the global median according to the World Health Organization (WHO) references (1). Stunting affects up to $32 \%$ of children living in developing countries; it is hence an important public health problem with a great impact on child health and development in these countries (2). Stunting has been declared a global health priority with WHO calling for a $40 \%$ reduction in the number of children who are stunted by 2025 (3).

In stunted children, short stature is not just the problem in itself, but rather stunting syndrome (4) in which various pathological changes happen that result in a suppression of linear growth, impairment of a child's cognitive development and reduced physical capacity of a child. The long-term consequences of stunting include decreased work capacity and an increased risk of poor health in adult life - childhood stunting is positively associated with obesity, metabolic syndrome and cardiac diseases in adult life. Moreover, stunting has also a transgenerational effect as mothers who were themselves stunted as children tend to have offspring with stunted growth, leading to an intergenerational cycle of growth impairment (4).
Several risk factors for childhood stunted growth have been identified. Maternal malnutrition during pregnancy affects future child growth (5). Childhood malnutrition either as inadequate overall caloric intake or deficiency in certain micronutrients is associated with growth failure (6). Recurrent infections such as diarrhoea and parasitic infestations as a result of poor sanitary living conditions are main risk factors for stunted growth in children in developing countries $(7,8)$. Despite numerous identifiable risk factors for childhood stunting, the effect of different risk factors varies in different regions and even in the same country $(9,10)$. Therefore, identification of local and environmental factors is important to establish local preventive strategies against stunted growth. Few studies on the prevalence of stunted growth and local factors associated with it have been done in Upper Egypt. To address this gap, we aimed to determine the prevalence of stunting and identify factors associated with stunting in schoolchildren in Sohag district, Upper Egypt.

\section{Methods}

\section{Study design and sample}

This was a cross-sectional study carried out from January 
2017 to May 2017 in Sohag district, Upper Egypt. Two public schools, one urban and one rural, were randomly selected.

All children aged between 4 and 12 years in these two schools were invited to participate, after obtaining parental consent. The exclusion criteria were: short stature children because of a known syndrome (e.g. Turner, Noonan, Russel-Silver and Prader-Willi syndromes, ascertained from the parents and examination by a paediatrician), children with contractures and kyphoscoliosis in whom accurate standing height could not be measured, and children whose parents did not agree to their participation in the study.

\section{Data collection}

The parents were interviewed at the schools by the researchers using a standardized questionnaire with two sections (11). The first section sought information on sociodemographic characteristics (age, residence, parental level of education, parental occupation, consanguinity between parents, family history of short stature, and child's birth order), and frequency of gastroenteritis in the child. Socioeconomic status of the family was estimated (11). All difficult or scientific terminology was explained to the parents. The second section recorded data from the examination of the children for signs of vitamin deficiency (angular stomatitis, cheilitis, bleeding gums, dry skin, brittle hair or nails, bruising, petechiae and seborrhoeic dermatitis). Laboratory investigations (haemoglobin level and stool analysis) were done to identify children with anaemia (haemoglobin level less than $10 \mathrm{~g} / \mathrm{dL}$ and children with parasitic infestations. Examinations were done by a nurse from the paediatric department at Sohag Faculty of Medicine.

Weight and standing height were measured by trained personnel with the child bare-footed and wearing only underwear. Measurements were recorded to the nearest $0.5 \mathrm{~kg}$ for weight and the nearest $1 \mathrm{~cm}$ for height. Body mass index (BMI) was calculated as the weight in kilograms divided by the height in metres squared $(\mathrm{kg} /$ $\mathrm{m}^{2}$ ). Stunting was defined as height for age and sex that is two standard deviations (SDs) or more below the WHO standard median (-2 z-score or below) (1).

\section{Statistical analysis}

Data were analysed using SPSS, version 22.0. Quantitative data are given as means and SDs, medians and ranges. Qualitative data are given as numbers and percentage. We tested the data for normality with the Shapiro-Wilk test but, as they were not normally distributed, we used nonparametric tests such as the Mann-Whitney test. The chi-squared test was used to compare qualitative variables. We considered the factors associated with short stature to include (i) family factors - parental eduction and employment, familial short stature, degree of consanguinity between parents, child's birth order in the family and socioeconomic status, and (ii) child factors presence of anaemia, parasite infestation and signs of vitamin deficiency, frequency of gastroenteritis and BMI.
Variables that were statistically significant in the univariate analysis, were included in a multivariate logistic regression analysis, and odds ratios (ORs) and 95\% confidence intervals (CIs) are given. All P-values were two-sided and the significance level was set at less than 0.05 .

\section{Ethical considerations}

The study was approved by the Ethical Committee of the Faculty of Medicine, Sohag University. We explained all the study details to the children's parents/guardians before taking informed consent.

\section{Results}

Of 2581 children aged 4-12 years in the two schools, 795 parents declined to give consent, giving a response rate of $69 \%$. Thus, 1786 children were enrolled in the study, of whom 329 (18.4\%) were stunted (-2 z-score or below), 95\% CI: $17.98-18.48 \%$. Of these 329 children, 76 (4.3\%) children had more severe stunting ( $-3 \mathrm{z}$-score or below). The characteristics of the studied children and their parents according to stature, excluding the 76 more severely stunted children, are shown in Table 1: 127 (14.6\%) of the boys and $126(15.0 \%)$ of the girls were stunted. The mean age of the children with stunting was 8.01 (SD 2.9) years with age range between 4 and 12 years. As regards residence, $135(15.4 \%)$ of the children in the rural area and 118 (14.1\%) in the urban area were stunted. No statistically significant differences were found between the stunted and normal-stature children for sex, age, place of residence, parental level of education and parental job.

The sociodemographic characteristics the children with more severe stunting ( $-3 \mathrm{z}$-score or below) are shown in Table 2. These children were excluded from further analysis because many cofounders were likely for the severely stunted children. In addition, there may have been an underlining pathological cause for their short stature. We therefore advised the parents to visit a paediatrician for examination and assessment of possible causes for their child's short stature.

Univariate analyses of associations between family and child characteristics and stunting showed that anaemia $(P<$ $0.001)$, parasite infestation $(P<0.001)$, familial short stature $(P<0.001)$, signs of vitamin deficiency $(P=0.04)$, BMI $(P<0.001)$, first-cousin consanguinity $(P=0.002)$ and frequent gastroenteritis $(P=0.002)$ were significantly associated with stunting(Table 3). However, socioeconomic status and birth order were not $(P>0.05)$.

Factors significantly associated with stunting in the univariate analysis were evaluated in a multivariate logistic regression analysis (Table 4). Parasite infestation $(\mathrm{OR}=1.8,95 \% \mathrm{CI}: 1.3-2.5 ; \mathrm{P}<0.001)$, anaemia $(\mathrm{OR}=1.7$, 95\% CI: 1.3-2.7; $P<0.001)$, BMI (OR = 1.2, 95\% CI: 1.1-1.3; $P<$ $0.001)$, frequent gastroenteritis $(\mathrm{OR}=1.1,95 \% \mathrm{CI}: 1.06-1.2$; $P=0.003)$, first-cousin consanguinity $(\mathrm{OR}=1.3,95 \% \mathrm{CI}$ : 1.2-1.6; $P=0.02)$ and familial short stature $(O R=1.5,95 \%$ CI 1.2-2.1; $P=0.04$ ) were independent factors associated with stunting in the children. 


\begin{tabular}{|c|c|c|c|}
\hline Variable & $\begin{array}{c}\text { Short } \\
\text { stature (-2 } \\
\text { z-score) }\end{array}$ & $\begin{array}{l}\text { Normal } \\
\text { stature }\end{array}$ & $\begin{array}{c}P \text { - } \\
\text { value }\end{array}$ \\
\hline Age (years) & & & 0.23 \\
\hline Mean (standard deviation) & $8.01(2.9)$ & $8.5(5.9)$ & \\
\hline Median(range) & $8(4-12)$ & $8(4-12)$ & \\
\hline Sex, no. (\%) & & & 0.830 \\
\hline Male & $127(14.6)$ & $742(85.4)$ & \\
\hline Female & $126(15.0)$ & $715(85.0)$ & \\
\hline Residence, no. (\%) & & & 0.450 \\
\hline Rural & $135(15.4)$ & $740(84.6)$ & \\
\hline Urban & $118(14.1)$ & $717(85.9)$ & \\
\hline Father's education, no. (\%) & & & 0.834 \\
\hline Illiterate & $24(12.6)$ & $166(87.4)$ & \\
\hline Read and write & $67(14.7)$ & $388(85.3)$ & \\
\hline Basic education & $46(20.1)$ & $183(97.9)$ & \\
\hline Secondary school & $85(13.4)$ & $550(86.6)$ & \\
\hline Higher education & $31(15.4)$ & $170(84.6)$ & \\
\hline Mother's education, no. (\%) & & & 0.484 \\
\hline Illiterate & $23(12.2)$ & $166(87.8)$ & \\
\hline Read and write & $66(14.2)$ & $399(85.8)$ & \\
\hline Basic education & $35(12.5)$ & $245(87.5)$ & \\
\hline Secondary school & $105(17.6)$ & $491(82.4)$ & \\
\hline Higher education & $24(13.3)$ & $156(86.7)$ & \\
\hline Father's job, no. (\%) & & & 0.347 \\
\hline Not working & $21(13.2)$ & $138(86.8)$ & \\
\hline Unskilled manual worker & $23(17.8)$ & $106(82.2)$ & \\
\hline Skilled manual worker/farmer & $77(15.9)$ & $408(84.1)$ & \\
\hline Trade/business & $93(14.4)$ & $555(85.6)$ & \\
\hline Semi-professional/clerk & $25(13.4)$ & $161(86.6)$ & \\
\hline Professional & $14(13.6)$ & $89(86.4)$ & \\
\hline Mother's job, no. (\%) & & & 0.223 \\
\hline Working & $92(13.5)$ & $589(86.5)$ & \\
\hline Not working & $161(15.6)$ & $868(84.4)$ & \\
\hline Total & $253(14.8)$ & $1457(85.2)$ & \\
\hline
\end{tabular}

\section{Discussion}

Children's growth is a complex process in which several genetic, nutritional and environmental factors are involved (12). The current study tried to assess the prevalence of stunting, and to explore some of the factors associated with stunting in schoolchildren in Sohag district.

We found that 329 (18.4\%) of the children had a heightfor-age z-score less than $2 \mathrm{SD}$. Although this prevalence is lower than that found in a study in 2011 on preparatoryschool children aged 11-14 years in Cairo, Egypt, which found a prevalence of stunting of $34.1 \%$ (13), our finding is consistent with other studies in developing countries: $17.4 \%$ in a Nigerian study conducted on 570 children aged 5-19 years (14), 24.5\% in a Kenyan study on 208 children aged 4-11 years (15) and $11.3 \%$ in an Indian study on 755 children aged between 4-16 years (16). The difference in
Table 2 Sociodemographic characteristics of the more severely stunted children ( -3 z-score or below)

$\begin{array}{lc}\text { Sociodemographic characteristic } & \text { Value } \\ \text { Age (years) } & \\ \text { Mean (standard deviation) } & 8(2.2) \\ \text { Median (range) } & 8(4-12) \\ \text { Sex, no. (\%) } & \\ \text { Male } & 36(47) \\ \text { Female } & 40(53) \\ \text { Residence, no. (\%) } & \\ \text { Rural } & 41(54) \\ \text { Urban } & 35(46) \\ \text { Father's education, no. (\%) } & \\ \text { Illiterate } & 8(11) \\ \text { Read and write } & 21(28) \\ \text { Basic education } & 36(47) \\ \text { Secondary school } & 4(5) \\ \text { Higher education } & 7(9) \\ \text { Mother's education, no. (\%) } & \\ \text { Illiterate } & 8(11) \\ \text { Read and write } & 10(13) \\ \text { Basic education } & 42(55) \\ \text { Secondary school } & 7(9) \\ \text { Higher education } & 9(12) \\ \text { Father's job, no. (\%) } & \\ \text { Working } & \\ \text { Not working } & 65(85.5) \\ \text { Mother's job, no. (\%) } & 11(14.5) \\ \text { Working } & \\ \text { Not working } & \\ \text { Total } & \\ & \\ & \end{array}$

the prevalence of stunting in different countries and even in different districts in the same country might be due to the effect of socioeconomic factors $(15,17,18)$. In line with the findings of the study conducted on preparatoryschool children in Cairo (13), we found that stunting was associated with a family history of short stature.

Age, sex, place of residence and parental education and job were not significantly associated with childhood stunting in our study. We also did not find an association between childhood stunting and the socioeconomic status of the family, which is in line with the result of the 2014 Egypt Demographic and Health Survey (19). These results indicate that stunting may not be a reflection of poverty and unavailability of food, but rather an indirect result of unhealthy nutritional habits and lack of family awareness about healthy nutrition required for growth of children.

Good nutrition is vital for children's growth.Abalanced diet, containing adequate calories from carbohydrates, fats and proteins, together with sufficient amounts of vitamins and minerals, is important for growth. Malnutrition is a main risk factor for stunting syndrome 


\begin{tabular}{|c|c|c|c|c|}
\hline Variable & Participants (\%) & $\beta$ coefficient (SE) & OR $(95 \% \mathrm{CI})$ & P-value \\
\hline \multicolumn{5}{|c|}{ Consanguinity between parents } \\
\hline No consanguinity & 43.1 & & $1^{a}$ & \\
\hline First cousin & 23.7 & $0.345(0.035)$ & $1.4(1.1-1.7)$ & 0.002 \\
\hline Second cousin & 27.7 & $0.264(0.012)$ & $1.1(0.78-1.4)$ & 0.215 \\
\hline Other relative & 5.5 & $-0.127(0.143)$ & $0.92(0.67-1.5)$ & 0.652 \\
\hline \multicolumn{5}{|l|}{ Familial short stature } \\
\hline Yes & 51.8 & $0.513(0.137)$ & $1.7(1.43-2.2)$ & $<0.001$ \\
\hline No & 48.2 & & $1^{\mathrm{a}}$ & \\
\hline Birth order & $\mathrm{n} / \mathrm{a}$ & $-0.044(0.059)$ & $0.96(0.86-1.1)$ & 0.453 \\
\hline \multicolumn{5}{|l|}{ Anaemia } \\
\hline Yes & 50.6 & $0.791(0.138)$ & $2.2(1.5-2.9)$ & $<0.001$ \\
\hline No & 49.4 & & $1^{\mathrm{a}}$ & \\
\hline \multicolumn{5}{|l|}{ Parasite infestation } \\
\hline Yes & 57.3 & $0.751(0.140)$ & $2.1(1.6-2.7)$ & $<0.001$ \\
\hline No & 42.7 & & $1^{\mathrm{a}}$ & \\
\hline \multicolumn{5}{|l|}{ Signs of vitamin deficiency } \\
\hline Yes & 52.6 & $0.275(0.136)$ & $1.3(1.1-1.7)$ & 0.04 \\
\hline No & 47.4 & & $1^{\mathrm{a}}$ & \\
\hline Frequency of enteritis & $\mathrm{n} / \mathrm{a}$ & $0.233(0.042)$ & $1.3(1.2-1.4)$ & 0.002 \\
\hline Body mass index & $\mathrm{n} / \mathrm{a}$ & $0.186(0.013)$ & $1.2(1.1-1.3)$ & $<0.001$ \\
\hline \multicolumn{5}{|l|}{ Socioeconomic status } \\
\hline Very low & 6.7 & $-0.543(0.123)$ & $0.3(0.1-1.2)$ & 0.437 \\
\hline Low & 41.6 & & $1^{\mathrm{a}}$ & \\
\hline Middle & 38.3 & $-0.348(0.254)$ & $0.5(0.2-1.4)$ & 0.215 \\
\hline High & 13.4 & $0.217(0.247)$ & $1.8(1.3-2.2)$ & 0.652 \\
\hline
\end{tabular}

SE: standard error, OR: odds ratio, CI: confidence interval, n/a: not applicable.

aReference category.

in children in developed countries, where malnourished children usually have multiple macronutrient and micronutrient deficiencies that predispose them to impaired immunity and recurrent infections, resulting in stunting $(6,20,21)$.

Our results show that stunted children had lower BMI. As BMI is a measure of nutritional status in children, this finding suggests that malnutrition is an important risk factor for stunting in children. We also identified that anaemia in our schoolchildren was associated with stunted growth (22). Several studies have found that multiple micronutrient deficiencies such as iron, zinc and vitamin A deficiency, are associated with short stature and stunting syndrome in children $(5,21,23)$. However, there is no strong evidence that correction of these micronutrients deficiencies increases the height of children suggesting that the relationship between micronutrient deficiencies and stunting is not causal.

Our findings provide evidence that parasitic infestation is one of the factors associated with stunting in children. Unhygienic living condition, especially in rural areas in developing countries like Upper Egypt,

Table 4 Multivariate logistic regression analysis of factors associated with stunting

\begin{tabular}{lccc}
\hline \multicolumn{1}{c}{ Table 4 Multivariate logistic regression analysis of factors associated with stunting } & & \\
\hline \multicolumn{1}{c}{ Variable } & $\boldsymbol{\beta}$ coefficient (SE) & Adjusted OR (95\% CI) & P-value \\
Parasite infestation & $0.606(0.158)$ & $1.8(1.3-2.5)$ & $<0.001$ \\
Anaemia & $0.564(0.155)$ & $1.7(1.3-2.7)$ & $<0.001$ \\
Body mass index & $0.193(0.015)$ & $1.2(1.1-1.3)$ & $<0.001$ \\
Frequent gastroenteritis & $0.247(0.053)$ & $1.1(1.06-1.2)$ & 0.003 \\
First-cousin consanguinity & $0.276(0.017)$ & $1.3(1.2-1.6)$ & 0.02 \\
Familial short stature & $0.440(0.152)$ & $1.5(1.2-2.1)$ & 0.04 \\
Signs of vitamin deficiency & $0.298(0.142)$ & $1.2(.89-1.7)$ & 0.261 \\
\hline
\end{tabular}

SE: standard error, OR: odds ratio, CI: confidence interval.

${ }^{a}$ Adjusted for all other variables. 
is still a main cause for recurrent gastroenteritis and parasitic infestation in children. In a previous study in Sohag governorate, $38.5 \%$ of children had parasitic infestations, $31.6 \%$ of whom had stunted growth (24). The relationship between parasitic infestation and stunting has been shown in studies conducted in other countries $(25,26)$. Intestinal parasitic infestations affect children's digestive and absorptive capacity and prevent them from obtaining essential nutrients required for growth.

We found childhood stunting was associated with frequent gastroenteritis episodes. Gastroenteritis is a common childhood infection, especially in areas with poor hygiene and sanitation. Although gastroenteritis has a short-term effect on growth after acute episodes, some studies have found that recurrent episodes of gastroenteritis have a cumulative effect and lead to a small but measurable effect on growth $(7,27)$. Moreover, frequent exposure to enteric pathogens, even if asymptomatic, may have a long-term effect on gut structure and function leading to villous atrophy with chronic intestinal inflammation and a mild form of malabsorption (28). In the context of poverty where the diet may lack or contain reduced amounts of essential nutrients, this modest malabsorption may exacerbate growth failure and result in stunting $(28,29)$.

Consanguineous marriage, especially first-cousin marriage, is common in our community. We found that first-cousin consanguineous marriage was associated with stunting in the offspring. In line with our results, an Egyptian study in 2006 found a small but statistically significant reduction in all investigated anthropometric measurements in the children of consanguineous parents (30). Similarly, the Cairo study in 2011 reported that positive parental consanguinity was a significant risk factor for low growth status in schoolchildren and the risk was greater in case of first-cousin parents.

Our study has some limitation. Because of time constraints, only two schools in one district were included, which reduced the sample population. To be able to generalize the results to larger groups, more schools in different districts would need to be included.

\section{Conclusion}

The prevalence of stunting in Sohag district is a considerable problem in comparison with developed countries which have a lower prevalence of stunting; for example, United States of America (2.1\% stunting), Australia (1.8\%) and Germany (1.3\%) (31). Family history of short stature, first-cousin consanguinity, anaemia, parasitic infestations, frequent gastroenteritis and low BMI were the most important factors associated with stunting in our sample of schoolchildren in Sohag. Therefore, we suggest that screening and treatment of parasitic infestation, provision of iron and multivitamin supplementations as well as education of children and parents about healthy nutrition should be a part of school health programmes to prevent stunting in schoolchildren.

\section{Acknowledgement}

We thank all the children and their families for their participation in the study.

\section{Funding: None}

Competing interests: None declared.

\section{Retard de croissance chez les écoliers en Égypte : prévalence et facteurs associés Résumé}

Contexte : Le retard de croissance nuit à la santé et au développement de l'enfant. Peu d'études sur la prévalence du retard de croissance et les facteurs qui y sont associés ont été menées en Haute Égypte.

Objectifs : La présente étude avait pour objectif de déterminer la prévalence du retard de croissance chez les écoliers de Sohag (Égypte), ainsi que les facteurs qui y sont associés.

Méthodes : La présente étude transversale a été menée en 2017 dans le gouvernorat de Sohag. Deux écoles publiques ont été sélectionnées de manière aléatoire (la première en zone urbaine et la seconde en zone rurale) et tous les enfants de ces établissements qui étaient âgés de 4 à 12 ans et dont les parents avaient donné leur consentement ont été inclus dans l'étude. Les parents ont été interrogés afin de recueillir des données sur les caractéristiques de l'enfant et de la famille. Les enfants ont été examinés pour détecter toute carence en vitamines, anémie ou parasitose, et leur indice de masse corporelle a été calculé. Une analyse de régression logistique multivariée a été réalisée pour déterminer quels facteurs étaient significativement corrélés au retard de croissance; les odds ratios (OR) et les intervalles de confiance (IC) à $95 \%$ sont indiqués.

Résultats : Au total, 1786 enfants ont participé à l'étude (taux de réponse de 69\%), dont 329 (18,4\%) souffraient d'un retard de croissance (correspondant à la valeur du Z, fixée à -2, ou à une valeur inférieure). Les facteurs significativement corrélés au retard de croissance étaient les suivants : infestation parasitaire $(\mathrm{OR}=1,8 ; \mathrm{IC}$ à $95 \%$ : 1,3-2,5), anémie ( $\mathrm{OR}=1,7$; IC à $95 \%: 1,3-2,7)$, faible indice de masse corporelle ( $\mathrm{OR}=1,2$; IC à 95\% : 1,1-1,3), gastroentérites fréquentes $(\mathrm{OR}=1,1$; IC à $95 \%: 1,06-1,2)$, consanguinité des parents avec un cousin de premier degré $(\mathrm{OR}=1,3$; IC à $95 \%: 1,2-1,6)$ et petite taille des membres de la famille (OR = 1,5; IC à $95 \%: 1,2-2,1)$. 
Conclusion : Le dépistage et le traitement des infestations parasitaires, la supplémentation en fer et en multivitamines et l'éducation en faveur d'une alimentation saine devraient faire partie des programmes de santé mis en œuvre par les établissements scolaires pour prévenir le retard de croissance chez les écoliers de Sohag.

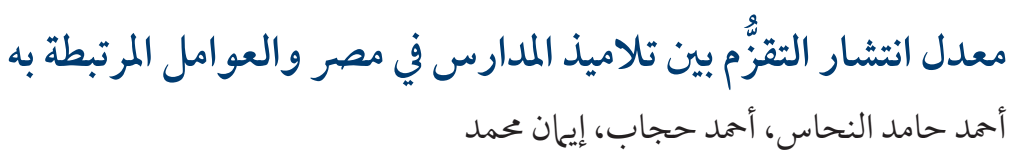

الخلاصة

$$
\begin{aligned}
& \text { الخلفية: يؤثر التقزُّم بصورة سلبية على صحة الأطفال ونحائهم. وقد أُجريت دراسات قليلة في صعيد مصر حول انتشار التقزٌّم والعو امل المُّتبطة به. } \\
& \text { الأهداف: هدفت هذه الدر اسة إلى تحديد مدى انتشار التقزٌّم بين تلاميذ المدارس في محافظة سوهاج، مصر، و والعو امل المُّتبطة بذلك. }
\end{aligned}
$$

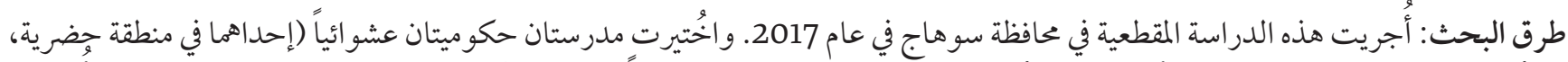

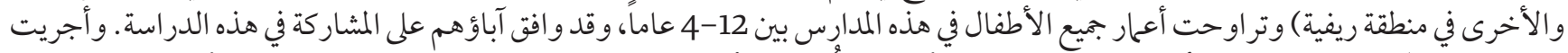

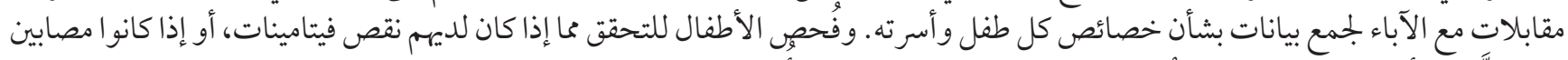

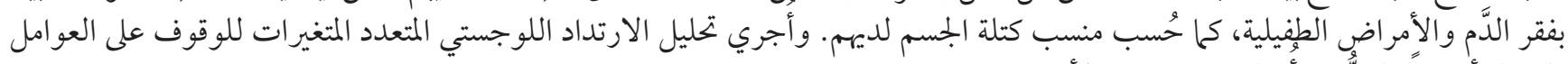

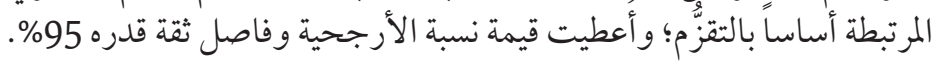

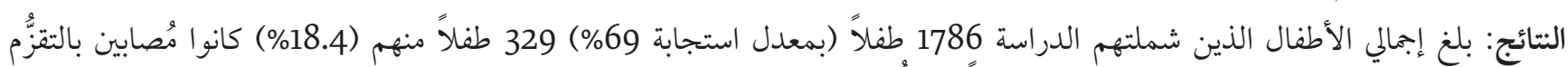

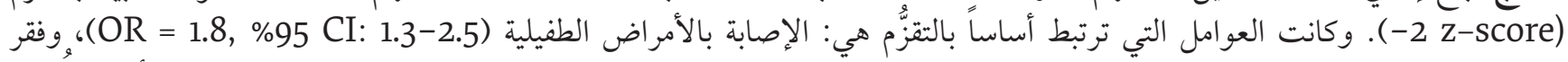

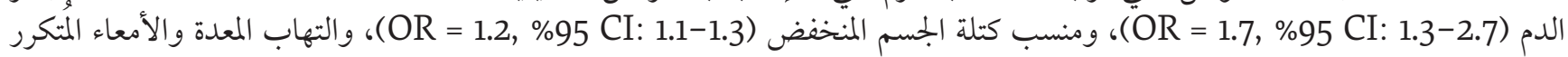
(OR = 1.1, \%95 CI: 1.06-1.2) و وكون الأبوين أولاد عم من الدرجة الأولى (OR = 1.3, \%95 CI: 1.2-1.6) وقصر القامة في الأسرة (OR ) . (OR $=1.5, \% 95 \mathrm{CI}: 1.2-2.1)$

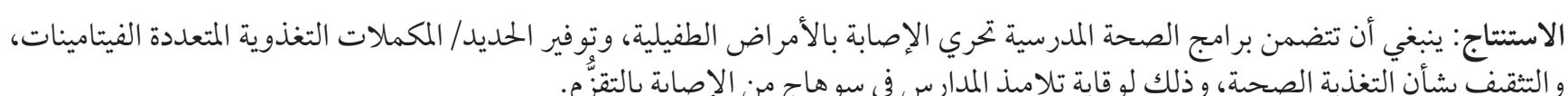

\section{References}

1. Neufeld LM, Osendarp SJ. Global, regional and country trends in underweight and stunting as indicators of nutrition and health of populations. Nestle Nutr Inst Workshop Ser. 2014;78:11-9. https://doi.org/10.1159/000354930

2. Stevens GA, Finucane MM, Paciorek CJ, Flaxman SR, White RA, Donner AJ, et al. Trends in mild, moderate, and severe stunting and underweight, and progress towards MDG 1 in 141 developing countries: a systematic analysis of population representative data. Lancet, 2012. 380(9844):824-34. https://doi.org/10.1016/So140-6736(12)60647-3

3. De Onis M, Dewey KG, Borghi E, AW Onyango, M Blössner, B Daelmans, et al. The World Health Organization's global target for reducing childhood stunting by 2025: rationale and proposed actions. Matern Child Nutr. 2013;9:6-26. https://doi.org/10.1111/ mcn.12075

4. Prendergast AJ, Humphrey JH. The stunting syndrome in developing countries. Paediatr Int Child Health. 2014;34(4):250-65. https://doi.org/ 10.1179/ 2046905514Y.0000000158

5. Black RE, Allen LH, Bhutta ZA, Caulfield LE, De Onis M, Ezzati M, et al. Maternal and child undernutrition: global and regional exposures and health consequences. Lancet. 2008;371(9608):243-6o. https://doi.org/10.1016/So140-6736(07)61690-0

6. Pelletier DL, Frongillo Jr EA, Schroeder DG, Habicht J-P. The effects of malnutrition on child mortality in developing countries. Bull World Health Org. 1995;73(4):443-8.

7. Checkley W, Buckley G, Gilman RH, Assis AM, Guerrant RL, Morris SS, et al. Multicountry analysis of the effects of diarrhoea on childhood stunting. Int J Epidemiol. 2008;37(4):816-30. https://doi.org/10.1093/ije/dyno99

8. Koski KG, Scott ME. Gastrointestinal nematodes, nutrition and immunity: breaking the negative spiral. Annu Rev Nutr. 2001;21(1):297-321. https://doi.org/10.1146/annurev.nutr.21.1.297

9. Frongillo Jr EA, de Onis M, Hanson KM. Socioeconomic and demographic factors are associated with worldwide patterns of stunting and wasting of children. J Nutr. 1997;127(12):2302-9. https://doi.org/10.1093/jn/127.12.2302

10. Shen T, Habicht J-P, Chang Y. Effect of economic reforms on child growth in urban and rural areas of China. N Engl J Med. 1996;335(6):400-6. https://doi.org/10.1056/NEJM199608083350606

11. El-Gilany A, El-Wehady A, El-Wasify M. Updating and validation of the socioeconomic status scale for health research in Egypt. East Mediterr Health J. 2012;18(9):962-8. https://doi.org/10.26719/2012.18.9.962

12. Dewey KG, Mayers DR. Early child growth: how do nutrition and infection interact? Matern Child Nutr. 2011;7:129-42. https:// doi.org/10.1111/j.1740-8709.2011.00357.x 
13. El-Moselhy EA, Barka YA, Abd-Allah ES, El-Awady S, Mansour A. Risk factors, impacts and anthropometric profile of low growth status; weight- and height-for-age among preparatory school children in Cairo, Egypt. J Am Sci. 2011;7(11):225-6.

14. Senbanjo IO, Oshikoya KA, Odusanya OO, Njokanma OF. Prevalence of and risk factors for stunting among school children and adolescents in Abeokuta, southwest Nigeria. J Health Popul Nutr. 2011;29(4):364. https://doi.org/10.3329/jhpn.v29i4.8452

15. Mwaniki E, Makokha A. Nutrition status and associated factors among children in public primary schools in Dagoretti, Nairobi, Kenya. Afr Health Sci. 2013;13(1):38-46. https://doi.org/10.4314/ahs.v13i1.6

16. Aroor AR, Airody SK, Mahale R, Sr R, Shetty S, Rao AR. Anthropometry and prevalence of common health problems among school going children in Surathkal, Karnataka. J Clin Diagn Res. 2014;8(12):PCo1-5. https://doi.org/10.7860/JCDR/2014/8769.5233

17. El Kishawi RR, Soo KL, Abed YA, Muda WAMW. Prevalence and associated factors influencing stunting in children aged 2-5 years in the Gaza Strip, Palestine: a cross-sectional study. BMC Pediatr. 2017;17(1):210. https://doi.org/10.1186/s12887-017-0957-y

18. Danaei G, Andrews KG, Sudfeld CR, Fink G, McCoy DC, Peet E, et al. Risk factors for childhood stunting in 137 developing countries: a comparative risk assessment analysis at global, regional, and country levels. PLoS Med. 2016;13(11):e1002164. https://doi. org/10.1371/journal.pmed.1002164

19. Ministry of Health and Population (Egypt), El-Zanaty and Associates (Egypt) and ICF International. Egypt Demographic and Health Survey 2014. Cairo and Rockville (MD): Ministry of Health and Population and ICF International; 2015. (https://dhsprogram.com/pubs/pdf/FR302/FR302.pdf, accessed 10 July 2017).

20. Jolly R. Early childhood development: the global challenge. Lancet. 2007;369(9555):8-9. https://doi.org/10.1016/So1406736(07)60007-5

21. Rytter MJH, Kolte L, Briend A, Friis H, Christensen VB. The immune system in children with malnutrition-a systematic review. PLoS One. 2014;9(8):e105017. https://doi.org/10.1371/journal.pone.0105017

22. Janus J, Moerschel SK. Evaluation of anemia in children. Am Fam Physicians. 2010;81(12):1462-71.

23. Muthayya S, Rah JH, Sugimoto JD, Roos FF, Kraemer K, Black RE. The global hidden hunger indices and maps: an advocacy tool for action. PLoS One. 2013;8(6):e6786o. https://doi.org/10.1371/journal.pone.0067860

24. El-Masry H, Ahmed Y, Hassan A, Zaky S, Abd-Allah E, El-Moselhy E, et al. Prevalence, risk factors and impacts of schistosomal and intestinal parasitic infections among rural school children in Sohag Governorate. Egypt J Hosp Med. 2007;29:616-30. https:// doi.org/10.12816/EJHM.2007.17705

25. Ahmed MM, el Hady HM. A preliminary survey of parasitic infections and nutritional status among school children in Riyadh, Saudi Arabia. J Egypt Soc Parasitol. 1989;19(1):101-5.

26. Neghina R, Neghina AM, Marincu I, Iacobiciu I. Epidemiology and history of human parasitic diseases in Romania. Parasitol Res. 2011;108(6):1333-46. https://doi.org/10.1007/s00436-011-2256-0

27. Richard SA, Black RE, Gilman RH, Guerrant RL, Kang G, Lanata CF, et al. Diarrhea in early childhood: short-term association with weight and long-term association with length. Am J Epidemiol. 2013;178(7):1129-38. https://doi.org/10.1093/aje/kwt094

28. Keusch GT, Rosenberg IH, Denno DM, Duggan C, Guerrant RL, Lavery JV, et al. Implications of acquired environmental enteric dysfunction for growth and stunting in infants and children living in low- and middle-income countries. Food Nutr Bull. 2013;34(3):357-64. https://doi.org/10.1177/156482651303400308

29. Humphrey JH. Child undernutrition, tropical enteropathy, toilets, and handwashing. Lancet. 2009;374(9694):1032-5. https://doi. org/10.1016/So140-6736(09)60950-8

30. Belal SK, Omar AA. Effect of parental consanguinity on anthropometric measurements among the children aged 11-13 years in a rural area of Assiut, Egypt. Egypt J Med Sci. 2006; 27(2): 30-5

31. World Health Organization. Global Database on Child Growth and Malnutrition. Countries and territories. World Health Organization; 2016 (http://www.who.int/nutgrowthdb/database/countries/en/, accessed 10 July 2017). 